\title{
Cry protein in the predatory mite Neoseiulus californicus and spider mite Tetranychus urticae prey fed with transgenic maize
}

\author{
P. D. Paulo ${ }^{a}$, M. A. M. Fadini ${ }^{a}$, A. B. Dominiquini ${ }^{a}$, S. M. Mendes ${ }^{b}$ and C. G. S. Marinho ${ }^{a}$ \\ ${ }^{a}$ Department of Agricultural Science, Federal University of São João Del-Rei, Rod. MG 424, Km 47, \\ CEP 35701-970, Sete Lagoas, MG, Brazil

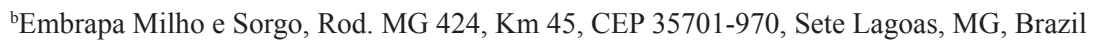 \\ *e-mail: fadini@ufsj.edu.br
}

Received: May 4, 2016 - Accepted: September 14, 2016 - Distributed: February 28, 2018

(With 1 figure)

The use of genetically modified insect-resistant crops (GM) with the gene from Bacillus thuringiensis (Bt) that express toxic proteins is an efficient means to control pests. Among these, Bt maize is the most widely grown crop (Ramirez-Romero et al., 2008).

The two-spotted spider mite Tetranychus urticae Koch (Acari: Tetranychidae), an organism non-targeted by the $B t$ maize protein, is one of the most important polyphagous pests in agriculture (Bolland et al., 1998; Capinera, 2001; Liburd et al., 2007; Moraes and Flechtmann, 2008; Opit et al., 2004). Several studies have studied the effects of Bt plants on insects (Dutton et al., 2002; Lozzia and Rigamonti, 1998; Lozzia, 1999; Pilcher et al., 1997). However, there are only a limited number of evaluated on phytophagous mites and predators (Castro et al., 2013; Fadini et al., 2012).

It is probable then that the Cry protein can be transferred from the mites to the third trophic level, the predators. The predatory mite Neoseiulus californicus McGregor (Acari: Phytoseiidae) feeds on mites of the family Tetranychidae (McMurtry and Croft, 1997) and can acquire the Cry protein by ingesting T. urticae mites that feed on Bt plants (Dutton et al., 2002; Obrist et al., 2006). Thus, aimed to evaluate the presence of Cry $1 \mathrm{~F}$ protein expressed in maize plants genetically modified, in phytophagous mite T. urticae and its predator $N$. californicus.

The experiment was conducted in a greenhouse and Agricultural Entomology Laboratory of the Federal University of São João del Rei (UFSJ), Sete Lagoas, Minas Gerais. It conducted the test with Bt-Cry1F Kit ImmunoStrip ${ }^{\circledR}$ Test for Cry $1 \mathrm{~F}$ protein detection 30F35HX $\mathrm{Bt}$ maize leaves in phytophagous mite $T$. urticae fed $\mathrm{Bt}$ maize 30F35HX leaves, and predator $N$. californicus fed $T$. urticae 30F35HX maintained in Bt maize leaves. The control was made by conventional isoline $30 \mathrm{~F} 35$, wherein the test was carried out in conventional maize leaves $30 \mathrm{~F} 35$ in T. urticae mite maintained in conventional corn plants, and predators $N$. californicus fed T. urticae kept in conventional maize leaves

The results were negative for the control group samples [i.e. conventional corn leaf discs (30F35), T. urticae and $N$. californicus], there was the formation of a control line on the Cry 1F ImmunoStrip ${ }^{\circledR}$ strips, as expected, confirming the absence of the Cry protein in the conventional maize plants (30F35) (Figure 1a). The results were positive with Bt maize leaf discs samples (30F35 Hx), in which a second test line was developed in the region between the control line and the lower end of the strip. This result confirms the presence of the Cry $1 \mathrm{~F}$ protein in leaves of the commercial hybrid maize 30F35 Hx (Figure 1b). The samples with phytophagous $T$. urticae mites that were fed with Bt maize, after contact with the Cry $1 \mathrm{~F}$ Immunustrip ${ }^{\circledR}$ strips, presented the formation of the control line and the test line, indicating the presence of the Cry $1 \mathrm{~F}$ protein in these mites (Figure 1c). Similarly, samples with the predator $N$. californicus which fed on T. urticae maintained on Bt maize leaves (30F35 Hx), presented a positive result, indicating the presence of the Cry protein in the $N$. californicus predatory mites (Figure 1d).

Results are from a qualitative test which reveals the presence or absence of the Cry $1 \mathrm{~F}$ protein. Thus, they indicate that the Cry $1 \mathrm{~F}$ protein present in $\mathrm{Bt}$ is transferred and accumulated in two-spotted spider mite T. urticae and the $N$. californicus predatory mite. The results also show that the Cry1F protein is transferred from the second to the third trophic level, i.e. to the predatory mite $N$. californicus. When feeding on T. urticae that fed on 30F35 Hx maize plants, $N$. californicus predatory mites accumulated protein from Bt Cry $1 \mathrm{~F}$ maize plants.

Although there was Cry protein accumulation in phytophagous mite T. urticae and predator N. californicus, as found, the protein does not affect biological and behavioral parameters of T. urticae (Ferreira, 2014). The Cry protein, present in varieties of $\mathrm{Bt}$ maize (Hx 30F35, 30F35 YG and Viptera Impact) did not alter the abundance of phytophagous 

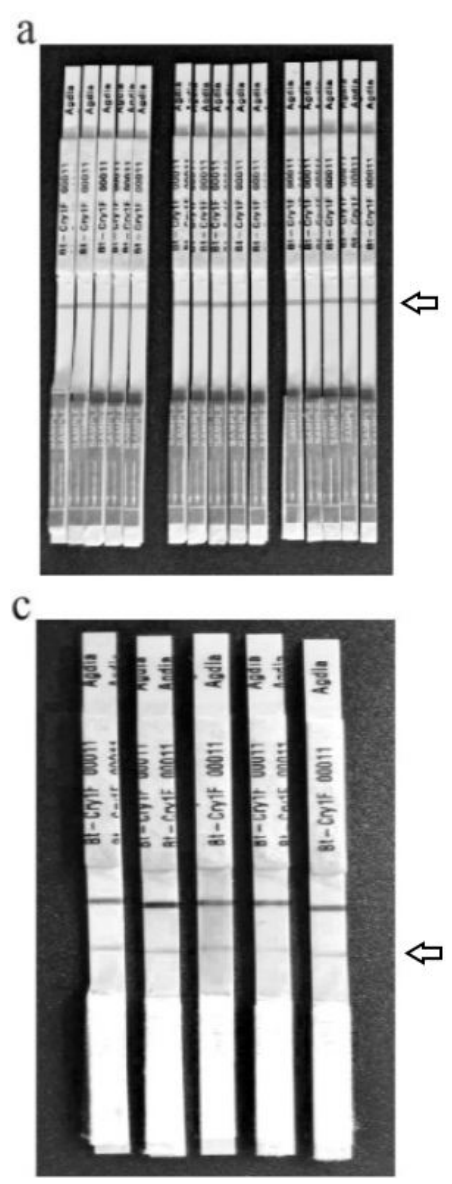

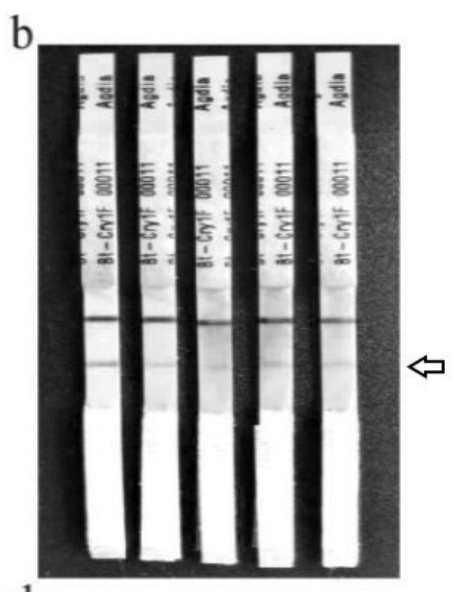

d

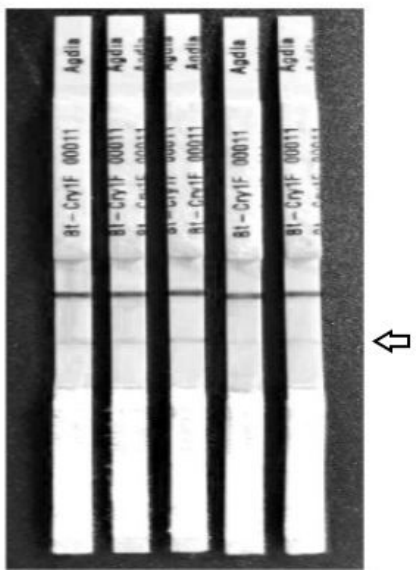

Figure 1. The arrow indicates positive band to cry protein presence. (a) ImmunoStrip ${ }^{\circledR}$ strips for Cry $1 \mathrm{~F}$ from the control sample (conventional maize leaves, T. urticae and N. californicus); (b) Strips ImmunoStrip ${ }^{\circledR}$ Cry1F from the sample with maize leaf discs Bt (30F35 Hx); (c) Strips ImmunoStrip ${ }^{\circledR}$ Cry1F from the sample with T. urticae fed Bt maize plants (30F35 Hx); (d) Strips ImmunoStrip ${ }^{\circledR}$ Cry1F, from the sample with predator N. californicus fed T. urticae kept in Bt corn plants $(30 \mathrm{~F} 35 \mathrm{Hx})$.

mites in the field, as well as the instantaneous rate of growth and food preference of T. urticae not differing in Bt and conventional maize (Ferreira, 2014). This work allowed us to assess the Cry protein expressed in Bt maize plants is transferred to the mite T. urticae and its predator N. californicus.

\section{Acknowledgements}

Financial support and scholarships were provided by the National Council of Scientific and Technological Development $(\mathrm{CNPq})$ and by the Minas Gerais State Foundation for Research Aid (FAPEMIG).

\section{References}

BOLLAND, H.R., GUTIERREZ, J. and FLECHTMANN, C.H.W., 1998. World catalogue of the spider mite family (Acari: Tetranychidae). Leiden: Brill Academic Publishers. 392 p.
CAPINERA, J.L., 2001. Hand book of vegetable pests. New York: Academic Press. 729 p.

CASTRO, T.R., AUSIQUE, J.J.S., NUNES, D.H., IBANHES, F.H. and DELALIBERA, J.I., 2013. Risk assessment of Cry toxins of Bacillus thuringiensis on the predatory mites Euseius concordis and Neoseiulus californicus (Acari: Phytoseiidae). Experimental \& Applied Acarology, vol. 59, no. 4, pp. 421-433. PMid:23053912. http://dx.doi.org/10.1007/s10493-012-9620-3.

DUTTON, A., KLEIN, H., ROMEIS, J. and BIGLER, F., 2002. Uptake of Bt-toxin by herbivores feeding on transgenic maize and consequences for the predator Chrysoperla carnea. Ecological Entomology, vol. 27, no. 4, pp. 441-447. http://dx.doi. org/10.1046/j.1365-2311.2002.00436.x.

FADINI, M.A.M., ARAUJO, O.G., MENDES, S.M. and MARINHO, C.G.S., 2012. Ocorrência do ácaro fitófago Catarhinus tricholaenae Keifer (Acari: Diptilomiopidae) em cultivares de milho Bt. Ciência Rural, vol. 42, no. 9, pp. 1524-1527. http:// dx.doi.org/10.1590/S0103-84782012000900001.

FERREIRA, T.E., 2014. Ácaros fitófagos em milho geneticamente modificado com o gene do Bacillus thuringiensis (Bt). Minas 
Gerais: Universidade Federal De São João Del-rei, 42 p. Masters Dissertation.

LIBURD, O.E., WHITE, J.C., RHODES, E.M. and BROWDY, A.A., 2007. The residual and direct effects of reduced-risk and conventional miticides on two-spotted spider mites, Tetranychus urticae (Acari: Tetranychidae), and predatory mites (Acari: Phytoseiidae). The Florida Entomologist, vol. 90, no. 1, pp. 249-257. http://dx.doi. org/10.1653/0015-4040(2007)90[249:TRADEO]2.0.CO;2.

LOZZIA, G.C., 1999. Biodiversity and structure of ground beetle assemblages (Coleoptera: Carabidae) in Bt corn and its effectson non-target insects. Bolletino di Zoologia Agraria e di Bachicoltura, vol. 31, no. 1, pp. 37-50.

LOZZIA, G.C. and RIGAMONTI, I.E., 1998. Preliminary study on the effects of transgenic maize on nontarget species. IOBC/ WPRS Bulletin, vol. 21, no. 8, pp. 171-180.

MCMURTRY, J.A. and CROFT, B.A., 1997. Life-styles of Phytoseiid mites and their roles in biological control. Annual Review of Entomology, vol. 42, no. 1, pp. 291-321. PMid:15012316. http://dx.doi.org/10.1146/annurev.ento.42.1.291.

MORAES, G.J. and FLECHTMANN, C.H.W., 2008. Manual de acarologia: acarologia básica e ácaros de plantas cultivadas no Brasil. Ribeirão Preto: Holos. 288 p.
OBRIST, L.B., DUTTON, A., ALBAJES, R. and BIGLER, F., 2006. Exposure of arthropod predators to Cry $1 \mathrm{Ab}$ toxin in $\mathrm{Bt}$ maize fields. Ecological Entomology, vol. 31, no. 2, pp. 143-154. http://dx.doi.org/10.1111/j.0307-6946.2006.00762.x.

OPIT, G.P., NECHOLS, J.R. and MARGOLIES, D.C., 2004. Biological control of twospotted spider mites, Tetranychus urticae Koch (Acari: Tetranychidae), using Phytoseiulus persimilis Athias-Henriot (Acari: Phytoseidae) on ivy geranium: assessment of predator release ratios. Biological Control, vol. 29, no. 3, pp. 445-452. http://dx.doi.org/10.1016/j. biocontrol.2003.08.007.

PILCHER, C.D., OBRYCKI, J.J., RICE, M.E. and LEWIS, L.C., 1997. Preimaginal development, survival, and field abundance of insect predators on transgenic Bacillus thuringiensis corn. Environmental Entomology, vol. 26, no. 2, pp. 446-454. http:// dx.doi.org/10.1093/ee/26.2.446.

RAMIREZ-ROMERO, R., DESNEUX, N., DECOURTYE, A., CHAFFIOL, A. and PHAM-DELÈGUE, M.H., 2008. Does $\mathrm{Cry} 1 \mathrm{Ab}$ protein affect learning performances of the honey bee Apis mellifera L. (Hymenoptera, Apidae)? Ecotoxicology and Environmental Safety, vol. 70, no. 2, pp. 327-333. PMid:18206234. http://dx.doi.org/10.1016/j.ecoenv.2007.12.002. 